\title{
Growth enhancement of maize (Zea mays L) through Azospirillum lipoferum inoculation : effect of plant genotype and bacterial concentration
}

\author{
JF Arsac, C Lamothe, D Mulard, J Fages* \\ Pioneer France-Maïs, chemin de l'Enseigure, 31840 Aussonne, France
}

(Received 9 March 1990; accepted 5 August 1990)

\begin{abstract}
Summary - Germination tests and pot experiments were carried out to study the specificity between an Azospirillum lipoferum strain and Zea mays hybrids. In both types of trial differences between hybrids were exhibited, and the influence of the plant genotype was clearly demonstrated. The optimal level for bacterial concentration was found to be $10^{7}$ bacteria per plant and the importance of an early inoculation was shown. Pot experiments were less precise than germination tests. Such germination tests for screening plant varieties using the criterion of plant-growth promotion appeared to be a very useful tool.
\end{abstract}

\section{Zea mays / Azospirillum lipoferum / germination tests / plant genotype / plant-growth promotion}

Résumé - Promotion de croissance du maïs (Zea mays) par inoculation avec Azospirillum lipoferum : influence du génotype de la plante hôte et de la dose d'inoculum. Des essais de germination et des essais en pots ont été utilisés pour étudier la spécificité de l'association entre une souche d'Azospirillum lipoferum et diverses variétés hybrides de maïs ainsi que la dose d'inoculum. L'influence du génotype de la plante hôte est clairement montrée dans les 2 types d'essais comme le montrent la figure 1 et le tableau $V$. Le niveau optimal de l'inoculation a été estimé à $10^{7}$ bactéries par plante et l'importance d'une inoculation précoce est démontrée (tableaux I, II, III). Les essais en pots sont moins sélectifs que les tests de germination (tableau IV). Ceux-ci s'avèrent très performants pour le criblage des variétés sur le critère de la croissance végétale.

Zea mays / Azospirillum lipoferum / test de germination / génotype de la plante hôte / promotion de croissance végétale

\section{INTRODUCTION}

Rhizospheric bacteria of the genus Azospirillum are known for their ability to improve grain and dry matter yields of crop plants (Yahalom et al, 1984; Wani et al, 1985; Fayez and Daw, 1987; Tilak and Subba Rao, 1987; Sarig et al, 1988).

The mechanism by which Azospirillum contributes to plant growth has remained a matter of controversy for years. Nowadays it is know that associative $\mathrm{N}_{2}$ fixation is often negligible in temperate regions and that additional processes should be considered in the beneficial effects observed (Michiels et al, 1989). An early effect of inoculation on root morphology and physiology has been shown: localization on and within wheat roots (Levanony et al, 1989), wheat root-hair branching (Jain and Patriquin, 1984), enhancement of mineral absorption (Baldani et al, 1983; Lin et al, 1983; Morgenstern and Okon, 1987; Sarig et al, 1988), root length, respiration rate and ATP-saving on tomato (Hadas and Okon, 1987).

The specificity of the plant-bacterium association is still controversial. According to Jain and Patriquin (1984) and Baldani and Döbereiner (1980), the results depend on the strain-host plant specificity, whereas for Okon and Hadar (1987) the effect is not strain-dependent within a species of Azospirillum or within different plant species.

\footnotetext{
" Correspondence and reprints
} 
In Zea mays, enhancement of root and shoot length were observed under controlled conditions (Fallik et al, 1988); in the field, Hegazi et al (1983) obtained yield increases in the Nile valley.

This paper describes the comparative use of 2 methods for measuring the inoculation effects of an Azospirillum lipoferum strain on Zea mays seedlings. The influence of bacterial concentration and plant genotype are investigated.

\section{MATERIALS AND METHODS}

\section{Cultivars}

In the germination tests and pot experiments, hybrids INRA 258, Dea (Pioneer Hi-bred Int) were used, and hybrids Pioneer Hi-bred Int, Marina, Licea, Dea, Eva, Fulvia, Volga and Sirena in the comparison between cultivars.

\section{Micro-organism}

The strain used was Azospirillum lipoferum CRT1 isolated from maize rhizosphere (Fages and Mulard, 1988).

\section{Medium}

AFM 10 medium was used (Fages, 1990); the composition was as follows (in $\mathrm{g} /$ ): $\mathrm{MgSO}_{4} \mathrm{H}_{2} \mathrm{O}, 0.2 ; \mathrm{NaCl}$, $0.1 ; \mathrm{CaCl}_{2}, 0.02 ; \mathrm{FeSO}_{4} 7 \mathrm{H}_{2} \mathrm{O}, 0.01 ; \mathrm{Na}_{2} \mathrm{MoO}_{4} 2 \mathrm{H}_{2} \mathrm{O}$, $0.002 ; \mathrm{KH}_{2} \mathrm{PO}_{4}, 0.4 ; \mathrm{K}_{2} \mathrm{HPO}_{4}, 0.6$; yeast extract, 3.0; glucose, $5.0 ; \mathrm{pH}$ adjusted to 7.2 with $\mathrm{NaOH} 10 \mathrm{~N}$. Sterilization was by autoclaving for $20 \mathrm{~min}$ at $121^{\circ} \mathrm{C}$. Glucose was separately sterilized under the same conditions.

\section{Inoculum preparation}

Inoculum was prepared in a $250-\mathrm{ml}$ Erlenmeyer flask containing $150 \mathrm{ml}$ medium. These flasks were incubated at $30^{\circ} \mathrm{C}$ on a rotative shaker for $24 \mathrm{~h}$. These cultures in late log-phase were centrifuged for $15 \mathrm{~min}$ at $4000 \mathrm{~g}$. Cells were resuspended in sterile distilled water, homogenized with a turbine (Ultraturrax, lka) and diluted until the desired cell concentration was reached for plantlet inoculation. Microbial population was determined by dilution plate counts on AFM 10 medium complemented with agar. Results were expressed as colony forming units (cfu).

\section{Germination tests}

One hundred Zea mays seeds were placed in a polystyrene box $(18 \times 15 \times 3 \mathrm{~cm})$ containing sterile Loire sand (from the Loire river, France) humidified with bacterial suspension (sand: suspension ratio $5: 1 \mathrm{v} / \mathrm{v}$, equivalent to $2.5 \mathrm{ml}$ inoculum per seed). The previously autoclaved inoculum was used as control; its concentration varied from one experiment to another. Seeds were covered with a $1-\mathrm{cm}$ thick sand layer then placed in a germination chamber at $18^{\circ} \mathrm{C}$ with a relative humidity of $70 \%$ for 5 days in darkness. Percentage of germination as well as coleoptile and primary root lengths were measured. Ten replicates of each treatment were made. Germination percentages were determined by deduction of dead or abnormal plantlets from total plant count. Lengths were measured on 10 plants sampled randomly.

\section{Pot experiments}

Twelve or 20 Zea mays seeds were placed in a pot over a water tank containing 2.5 I of sterile Loire sand. The sand had been previously humidified with demineralized water (sand: water ratio, 5:1 v/v). Inoculation was achieved by placing $1 \mathrm{ml}$ bacterial suspension on each seed. The previously autoclaved inoculum was used as control. When several inoculum concentrations were tested, the intermediate level $\left(10^{7} \mathrm{cfu} / \mathrm{ml}\right)$ was chosen for autoclaving. Seeds were then covered with a 1-cm thick layer of sand. Ten replicates of each treatment were made. Pots were placed in a germination chamber for 14 days with a photoperiod of $14 \mathrm{~h}$ light and $10 \mathrm{~h}$ dark and a synchronous thermoperiod of $25 / 20^{\circ} \mathrm{C}$. Plant nutritive requirements were covered by the following presterilized solution (in $\mathrm{mg} / \mathrm{l}$ ): $\mathrm{KNO}_{3}$, 384; $\mathrm{K}_{2} \mathrm{HPO}_{4}, 54 ; \mathrm{KH}_{2} \mathrm{PO}_{4}, 109 ; \mathrm{NaNO}_{3}, 17 ; \mathrm{NaCl}$, 12; $\mathrm{NH}_{4} \mathrm{NO}_{3}, 16 ; \mathrm{Ca}\left(\mathrm{NO}_{3}\right)_{2} 4 \mathrm{H}_{2} \mathrm{O}, 732 ; \mathrm{MgSO}_{4} 7 \mathrm{H}_{2} \mathrm{O}$, 185; $\mathrm{FeSO}_{4} 7 \mathrm{H}_{2} \mathrm{O}, 1$; $\mathrm{ZnSO}_{4} \mathrm{H}_{2} \mathrm{O}, 1 ; \mathrm{H}_{3} \mathrm{BO}_{3}, 1$; $\mathrm{CuSO}_{4} 5 \mathrm{H}_{2} \mathrm{O}, 0.03 ; \mathrm{MnSO}_{4} 4 \mathrm{H}_{2} \mathrm{O}, 0.1 ;\left(\mathrm{NH}_{4}\right)_{2} \mathrm{MOO}_{4}$, 0.03 . At emergence (after 4 days), thinning out of seedlings was carried out leaving 9 out of 12 or 16 out of 20 plantlets per pot. At harvest after 14 days, the following measurements were performed: root surface area, root and shoot dry matter.

\section{Titrimetric measurement of root surface area (Carley and Watson, 1966)}

The root system was washed with demineralized water to eliminate all the sand particles remaining on the root system. After excision, roots were drained for $3 \mathrm{~h}$. Each root system was then soaked for $15 \mathrm{~s}$ in $\mathrm{HCl}$ $3 \mathrm{~N}$. Excess acid elimination was performed in a manual centrifugal dryer. Roots were then left in $300 \mathrm{ml}$ of demineralized water with gentle shaking. $100 \mathrm{ml}$ of this solution was then titrated with $\mathrm{NaOH} 0.25 \mathrm{~N}$ and phenolphtalein as dye indicator. Results were ex- 
pressed in $\mathrm{ml}$ of poured $\mathrm{NaOH}$. Roots and shoots were then placed in a ventilated drying oven for $48 \mathrm{~h}$ at $85^{\circ} \mathrm{C}$ for dry matter determination.

\section{Statistical analysis}

Variance analyses were followed by Newman-Keuls test when Fisher test probability was $<5 \%$.

\section{RESULTS}

\section{Germination tests}

No modification in the percentages of germination was observed (data not shown).

\section{Effect of bacterial concentration}

A preliminary experiment carried out with $6 \times 10^{9}$ $\mathrm{cfu} / \mathrm{ml}$ (table I) showed an inhibition of root growth. A non-significant decrease in shootlength was observed with both cultivars.

Another experiment was set up with 3 different bacterial concentrations of inoculum: $0.9 \times 10^{9}$, $0.9 \times 10^{7}$ and $0.9 \times 10^{5} \mathrm{cfu} / \mathrm{ml}$. At the highest concentration, no difference in length from control was observed (table Ii). A significant increase in primary root elongation was obtained with the 2 other bacterial concentrations. However, a decrease in shoot length with the lowest bacterial density was obtained.

Table III shows results from trials using the same protocol but carried out at different dates. Four inoculum levels were tested in these trials.
Table I. Germination tests. Effect of inoculation with $A$ lipoferum CRT1 at $6.0 \times 10^{9} \mathrm{cfu} / \mathrm{ml}$ on root and shoot lengths of 2 hybrids of Zea mays.

\begin{tabular}{|c|c|c|c|c|}
\hline \multirow[t]{2}{*}{ Hybrid } & \multicolumn{2}{|c|}{ INRA 258} & \multicolumn{2}{|c|}{$D E A$} \\
\hline & Control & Inoculated & Control & Inoculated \\
\hline $\begin{array}{l}\text { Shoot length } \\
(\mathrm{mm})\end{array}$ & $41.8 \mathrm{a}$ & $40.6 \mathrm{a}$ & $46.7 a$ & $43.4 \mathrm{a}$ \\
\hline $\begin{array}{l}\text { Primary root } \\
\text { length }(\mathrm{mm})\end{array}$ & $93.3 b$ & $80.3 \mathrm{c}$ & $121.9 b$ & $86.1 \mathrm{c}$ \\
\hline
\end{tabular}

Mean values having common letter within each cultivar are not significantly different at 0.05 level (Newman-Keuls test).

Table II. Germination tests. Effect of bacterial concentration of $A$ lipoferum CRT1 on root and shoot lengths of Zea mays (cv Dea).

\begin{tabular}{lcc}
\hline $\begin{array}{c}\text { Bacterial } \\
\text { concentration } \\
(c f u / m)\end{array}$ & Shoot length & $\begin{array}{c}\text { Primary root } \\
\text { length } \\
(\mathrm{mm})\end{array}$ \\
\hline & $(\mathrm{mm})$ & \\
$0.9 \times 10^{9}$ & & $94.3 \mathrm{ab}$ \\
$0.9 \times 10^{7}$ & $37.0 \mathrm{a}$ & $95.5 \mathrm{a}$ \\
$0.9 \times 10^{5}$ & $37.6 \mathrm{a}$ & $95.8 \mathrm{a}$ \\
Autoclaved control & $33.8 \mathrm{~b}$ & $91.2 \mathrm{~b}$ \\
& $36.3 \mathrm{a}$ & \\
\hline
\end{tabular}

Mean values having common letter within a column are not significantly different at 0.05 level (Newman-Keuls test). Control is the intermediate concentration culture autoclaved.

Table III. Germination tests. Effect of bacterial concentration of $A$ lipoferum CRT1 in 4 trials on root and shoot lengths of Zea mays (cv Dea).

\begin{tabular}{|c|c|c|c|c|c|}
\hline \multirow[t]{2}{*}{$\begin{array}{l}\text { Trial } \\
\text { No }\end{array}$} & \multirow{2}{*}{$\begin{array}{c}\text { Bacterial } \\
\text { concentration } \\
\text { (cfu/ml) }\end{array}$} & \multicolumn{2}{|c|}{$\begin{array}{l}\text { Shoot length } \\
(\mathrm{mm})\end{array}$} & \multicolumn{2}{|c|}{$\begin{array}{l}\text { Primary root } \\
\text { length }(\mathrm{mm})\end{array}$} \\
\hline & & Control & Inoculated & Control & Inoculated \\
\hline 1 & $1.0 \times 10^{6}$ & $42.9 \mathrm{a}$ & $45.3 b$ & $106.2 \mathrm{c}$ & $108.1 \mathrm{c}$ \\
\hline 2 & $5.0 \times 10^{6}$ & $47.1 \mathrm{a}$ & $48.6 \mathrm{~b}$ & $105.2 \mathrm{c}$ & $110.3 d$ \\
\hline 3 & $1.0 \times 10^{7}$ & $34.7 \mathrm{a}$ & $37.6 \mathrm{~b}$ & $80.0 \mathrm{c}$ & $92.4 \mathrm{~d}$ \\
\hline 4 & $1.0 \times 10^{8}$ & $40.4 a$ & $42.5 \mathrm{~b}$ & $87.6 \mathrm{c}$ & $90.7 d$ \\
\hline
\end{tabular}

Mean values having common letter within a trial are not significantly different at 0.05 level (Neuwman-Keuls test). Length variations between trials are caused by test duration which may vary by a few hours after 5 days. For each trial, control is the bacterial culture autoclaved. 
Apart from the lowest concentration which exhibited no difference, all the other inoculations led to a significant increase in root elongation. The highest increases were obtained with the 2 intermediate concentrations. The bacterial density effect on shoot length was less pronounced, since a significant increase was observed with all the inoculum concentrations.

\section{Effect of the genotypes of 7 maize hybrids}

To test host-plant genotype, the level of $1.0 \mathrm{x}$ $10^{7} \mathrm{cfu} / \mathrm{ml}$ was chosen. Besides the Dea hybrid already tested with this concentration, 6 new cultivars were tested (fig 1). Four hybrids, Eva, Fulvia, Dea and Marina, exhibited a positive response to both criteria. Shoot elongation was respectively increased by $13.1 \%, 10.2 \%, 8.4 \%$ and $7.8 \%$. Root elongation was respectively increased by $4.3 \%, 3.0 \%, 5.0 \%$ and $3.1 \%$. In Volga, a significant increase in root elongation of $3.8 \%$ was observed. In Licea, in spite of a $5 \%$ increase in shoot length, no significant difference was observed. Finally an inhibition of root growth was obtained with Sirena.
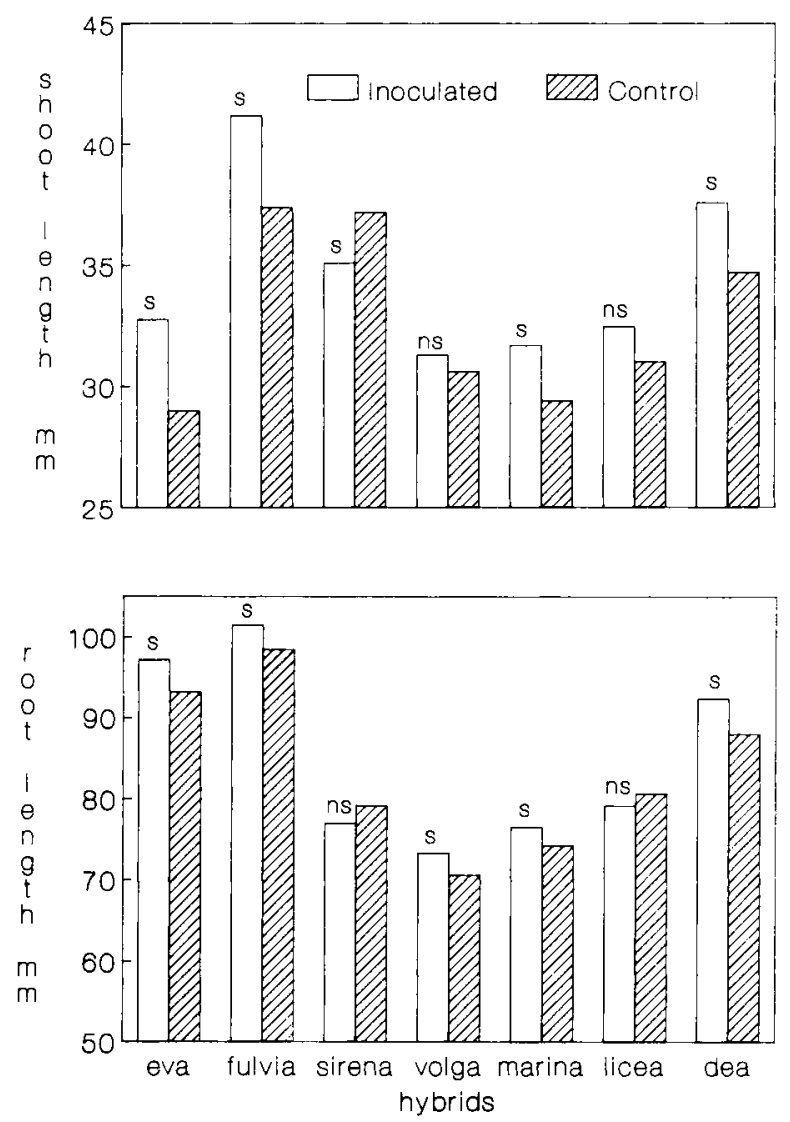

Fig 1. Germination tests. Primary root and shoot lengths of Zea mays hybrids through inoculation with $A$ lipoferum CRT1 at $1.0 \times 107 \mathrm{cfu} / \mathrm{ml} \mathrm{s}$, significantly different at 0.05 level (Newman-Keuls tests); ns, not significantly different at 0.05 level (Newman-Keuls test).

\section{Pot experiments}

\section{Effect of bacterial concentration}

In the first experiment, 3 bacterial concentrations of $0.9 \times 10^{9}, 0.9 \times 10^{7}$ and $0.9 \times 10^{5} \mathrm{cfu} / \mathrm{ml}$ were tested for 14 days with 16 plants per pot. As shown in table IV, a significant increase in root surface area $(13.5 \%)$ was obtained for the intermediate level. No significant difference with the other parameters was observed, due to too wide a biological variation.

Nevertheless, in all cases measurements on inoculated plants gave higher values than those obtained with control plants. In a second trial carried out with 9 plants, 3 other concentrations, 1.0 $\times 10^{8}, 1.0 \times 10^{7}$ and $1.0 \times 10^{6} \mathrm{cfu} / \mathrm{ml}$, were tested.

There was too great a dispersion in the measurements for the statistical threshold to be reached on root dry matter and root surface area. However, the intermediate inoculum concentration gave the highest values. On aerial parts, a significant increase in dry matter was obtained whatever the inoculum concentration.

\section{Effect of the genotypes of 5 maize hybrids}

Two hybrids, Volga and Licea, tested in the germination tests, were not assayed here. The lar-

Table IV. Pot experiment. Effect of bacterial concentration of $A$ lipoferum CRT1 on root surface area and dry weight of Zea mays (cv Dea).

\begin{tabular}{|c|c|c|c|}
\hline $\begin{array}{c}\text { Bacterial } \\
\text { concentration } \\
\text { (cfu/ml) }\end{array}$ & $\begin{array}{c}\text { Root surface } \\
\text { area } \\
\text { (m/ NaOH/pot) }\end{array}$ & $\begin{array}{c}\text { Shoot } \\
\text { dry weight } \\
(g / p o t)\end{array}$ & $\begin{array}{c}\text { Root } \\
\text { dry weight } \\
(g / p o t)\end{array}$ \\
\hline
\end{tabular}

Trial 1

$\begin{array}{llll}0.9=10^{9} & 14.8 \mathrm{a} & 2.45 \mathrm{a} & 2.07 \mathrm{a} \\ 0.9 \times 10^{7} & 15.1 \mathrm{~b} & 2.40 \mathrm{a} & 2.18 \mathrm{a} \\ 0.9 \times 10^{5} & 13.5 \mathrm{a} & 2.36 \mathrm{a} & 2.01 \mathrm{a} \\ \text { Control } & 13.3 \mathrm{a} & 2.33 \mathrm{a} & 1.99 \mathrm{a} \\ \text { Trial } 2 & & & \\ 1.0 \times 10^{8} & 10.3 \mathrm{a} & 1.99 \mathrm{a} & 0.56 \mathrm{a} \\ 1.0 \times 10^{7} & 11.1 \mathrm{a} & 2.02 \mathrm{a} & 0.61 \mathrm{a} \\ 1.0 \times 10^{6} & 9.6 \mathrm{a} & 2.08 \mathrm{a} & 0.54 \mathrm{a} \\ \text { Control } & 9.4 \mathrm{a} & 1.75 \mathrm{~b} & 0.57 \mathrm{a}\end{array}$

Mean value having common letter within trial and within a column are not significantly different at 0.05 level (NewmanKeuls test). Control is the intermediate concentration culture autoclaved. 
gest significant effects were obtained on Dea root surface area ( $+21 \%$ over control) and on Eva shoot dry matter $(+7 \%)$. No other differences were obtained with these 2 cultivars (table $V$ ). Responses of the 3 other plant varieties to inoculation were non-significant.

Table V. Pot experiments. Effect of inoculation with $A$ lipoferum CRT1 at $1.0 \times 10^{7} \mathrm{cfu} / \mathrm{ml}$ on root surface area and dry weight of different Zea mays hybrids.

\begin{tabular}{|c|c|c|c|}
\hline brid & $\begin{array}{l}\text { Root surface } \\
\text { area } \\
\text { (m/ NaOH/pot) } \\
\text { Control Inoc }\end{array}$ & $\begin{array}{c}\text { Root } \\
\text { dry weight } \\
\text { (g/pot) } \\
\text { Control Inoc }\end{array}$ & $\begin{array}{c}\text { Shoot } \\
\text { dry weight } \\
\text { (g/pot) } \\
\text { Control inoo }\end{array}$ \\
\hline
\end{tabular}

$\begin{array}{lrrrrrr}\text { Marina } & 9.6 \mathrm{a} & 9.7 \mathrm{a} & 0.64 \mathrm{c} & 0.65 \mathrm{c} & 1.97 \mathrm{~d} & 2.03 \mathrm{~d} \\ \text { Dea } & 13.4 \mathrm{a} & 17.0 \mathrm{~b} & 0.65 \mathrm{c} & 0.68 \mathrm{c} & 2.34 \mathrm{~d} & 2.37 \mathrm{~d} \\ \text { Eva } & 8.3 \mathrm{a} & 8.0 \mathrm{a} & 0.80 \mathrm{c} & 0.77 \mathrm{c} & 1.49 \mathrm{~d} & 1.60 \mathrm{e} \\ \text { Fulvia } & 17.8 \mathrm{a} & 17.1 \mathrm{a} & 0.88 \mathrm{c} & 0.91 \mathrm{c} & 2.38 \mathrm{~d} & 2.42 \mathrm{~d} \\ \text { Sirena } & 10.3 \mathrm{a} & 10.6 \mathrm{a} & 0.59 \mathrm{c} & \mathbf{0 . 6 0 c} & 2.21 \mathrm{~d} & 2.26 \mathrm{~d}\end{array}$

Mean values having common letter within a hybrid are not significantly different at 0.05 level (Newman-Keuls test).

\section{DISCUSSION}

The different parameters checked in germination tests did not show the same sensitivity to bacterial inoculation. The percentage of germination was not affected. This qualitative criterion may not be suitable for demonstrating growth promotion. Moreover, it is related to seed physiology rather than to external effects.

Root elongation was the best parameter for displaying differences between inoculum concentrations. This is evidence that it is the root development of plantlets which is directly affected by bacterial inoculation. Under our experimental conditions, the optimal inoculum level was $1.0 \times$ $10^{7} \mathrm{cfu} / \mathrm{ml}$ or $2.5 \times 10^{7} \mathrm{cfu} / \mathrm{plant}$. Lower bacterial densities led to lower responses. These results are in agreement with the findings of Fallik et al (1988) on Zea mays, while Kapulnik et al (1985) found an optimal inoculum level for wheat of between $10^{5} \mathrm{cfu} / \mathrm{plant}$ and $10^{6} \mathrm{cfu} / \mathrm{plant}$. Beyond $10^{9} \mathrm{cfu} / \mathrm{ml}$, a clear inhibition was observed.

Shoot elongation was also increased through inoculation. However, this parameter was less sensitive to the number of bacteria applied.
These results show a very early effect of Azospirillum inoculation on Zea mays. With another crop (Panicum miliaceum), similar effects were obtained by Harari et al (1989) on root elongation and root-hair development.

The effect of Zea mays inoculation by Azospirillum lipoferum CRT1 was host-plant genotype dependent since coleoptile elongation varied from $-5.6 \%$ to $+13.1 \%$ and primary root length varied from $-2.8 \%$ to $+5.8 \%$ over control. Figure 1 illustrates these results, showing that germination tests are a powerful tool for the screening of plant-bacteria associations on the plant-growth promotion criterion. This is a decisive step forward compared with classical screening methods performed with indirect criteria such as biological nitrogen fixation (Ela et al, 1982; Thomas-Bauzon et al, 1982) or phytohormone production (Zimmer and Böthe, 1989).

Pot experiment results showed that inoculation effects were still observable after 2 weeks' growth. The increases obtained had the same order of magnitude as those observed after 5 days. However, the biological variation was at this development stage more pronounced, and consequently, results were less often statistically significant.

For root surface area improvement, the optimal inoculum level appeared to be $1.0 \times 10^{7} \mathrm{cfu} /$ plant. No correlation between root dry matter and root surface area was found. The better development of the root system which can be easily observed de visu was not converted into root dry matter variations measurables after 14 days of growth. Titrimetric measurement of root surface area is the best method for evidencing differences among inoculum concentrations. As shown by the trial with several plant varieties, this method was not suitable for hybrid screening. Compared with the germination tests method, it has 3 major disadvantages. It is longer, involves more work and is less discriminative.

Azospirillum lipoferum CRT1 growthpromotion effect on Zea mays began from the very early plant development stages and remained observable after 2 weeks. It could be measured on several parameters, and depended on both the inoculum concentration and the host-plant genotype. These findings suggest that the yield enhancements in the field came, at least partly, from such early root-growth promotion effects. 
The methods described here, particularly the germination tests, indicated which bacterial strain-cultivar pair should be preferably chosen and which inoculum level was optimal. Moreover, the precocity of the observed effects showed that the period immediately following planting is crucial. Hence, one wonders, if the fate of the inoculated strain in the rhizosphere is really. important beyond the few days during which the growth-promotion effect acts. The inoculum formulation (Fages, 1990) and the methodology of field application is therefore very important and must allow a good root colonization at the beginning of plant growth. These methods are under current investigation in our laboratory.

\section{ACKNOWLEDGMENT}

We thank $\mathrm{G}$ Lafargue from Sica France-Maïs quality control laboratory for helping us with the protocol design.

\section{REFERENCES}

Baldani VLD, Döbereiner $J(1980)$ Host-plant specificity in the infection of cereals with Azospirillum spp. Soil Biol Biochem 12, 433-439

Baldani VLD, Baldani Jl, Döbereiner J (1983) Effects of Azospirillum inoculation on root infection and nitrogen incorporation in wheat. Can $J$ Microbiol 29, 924-929

Carley HE, Watson RD (1966) A new gravimetric method for estimating root-surface area. Soil Sci $102,289-291$

Ela WS, Anderson MA, Brill JW (1982) Screening and selection of maize to enhance associative bacterial nitrogen fixation. Plant Physiol 70, 1564-1567

Fages J (1990) An optimized process for manufacturing an Azospirillum inoculant for crops. Appl Microbiol Biotechnol 32, 473-478

Fages J, Mulard D (1988) Isolement de bactéries rhizosphériques et effet de leur inoculation en pots chez Zea mays. Agronomie 8, 309-314

Fallik E, Okon Y, Fischer M (1988) Growth response of maize roots to Azospirillum inoculation: effect of soil organic matter content, number of rhizosphere bacteria and timing of inoculation. Soil Biol Biochem 20, 45-49

Fayez M, Daw ZY (1987) Effect of inoculation with different strains of Azospirillum brasilense on cotton (Gossypium barbadense). Biol Fertil Soils 4, 91-95

Hadas R, Okon Y (1987) Effect of Azospirillum brasilense inoculation on root morphology and respiration in tomato seedlings. Biol Fertil Soils 5, 241-247
Harari A, Kigel J, Okon Y (1989) Involvment of IAA in the interaction between Azospirillum brasilense and Panicum miliaceum roots. In: Development in Plant and Soil Sciences (Skinner FA, Boddey RM, Fendrik I, eds) Kluwer Academic Publishers, Dordrecht, Holland, vol 35, pp 137-145

Hegazi NA, Monib M, Amer HA, Shokr El S (1983) Response of maize plants to inoculation with azospirilla and (or) straw amendment in Egypt. Can J Microbiol 29, 888-894

Jain DK, Patriquin DG (1984) Root hair deformation, bacterial attatchment and plant growth in wheatAzospirillum associations. Appl Environ Microbiol $48,1208-1213$

Kapulnik Y, Okon Y, Henis $Y(1985)$ Changes in root morphology of wheat caused by Azospirillum inoculation. Can J Microbiol 31, 881-887

Levanony H, Bashan Y, Romano B, Klein E (1989) Ultrastructural localization and identification of Azospirillum brasilense $\mathrm{Cd}$ on and within wheat roots by immuno-gold labeling. Plant Soil 117, 207-218

Lin W, Okon Y, Hardy R (1983) Enhanced mineral uptake by Zea mays and Sorghum bicolor roots inoculated with Azospirillum brasilense. Appl Environ Microbiol 45, 1775-1779

Michiels K, Vanderleyden J, Van Gool A (1989) Azospirillum-plant root associations: a review. Biol Fertil Soils 8, 356-368

Morgenstern E, Okon $Y$ (1987) Promotion of plant growth and $\mathrm{NO}_{3}^{-}$and $\mathrm{Rb}^{+}$uptake in Sorghum bicolor $\times$ Sorghum sudanense inoculated with Azospirillum brasilense. Arid Soil Res Rehabil 1, 211-217

Okon $Y$, Hadar $Y$ (1987) Microbial inoculants as cropyield enhancers. CRC Crit Rev Biotechnol 6, 61-85

Sarig S, Blum A, Okon Y (1988) Improvement of the water status and yield of field-grown grain sorghum (Sorghum bicolor) by inoculation with Azospirillum brasilense. J Agric Sci (Camb) 110, 271-277

Tilak KVBR, Subba Rao NS (1987) Association of Azospirillum brasilense with pearl millet (Pennisetum americanum (L) cv Leeke). Biol Fertil Soils 4, 97-102

Thomas-Bauzon D, Weinhard $P$, Villecourt $P$, Balandreau J (1982) The spermosphere model. I. Its use in growing, counting, and isolating $\mathrm{N}_{2}$-fixing bacteria from the rhizosphere of rice. Can J Microbiol 28, 922-928

Wani SP, Chandrapalaiah S, Dart PJ (1985) Response of pearl millet cultivars to inoculation with nitrogen-fixing bacteria. Exp/ Agric 21, 175-182

Yahalom E, Kapulnik Y, Okon $Y$ (1984) Response of Setaria italica to inoculation with Azospirillum brasilense as compared to Azotobacter chroococcum. Plant Soil 82, 77-85

Zimmer W, Böthe H (1989) The phytohormonal interactions between Azospirillum and wheat. In: De velopment in Plant and Soil Sciences (Skinner FA, Boddey RM, Fendrik I, eds) Kluwer Academic Publishers, Dordrecht, Holland, vol 35, pp 137-145 